\title{
Antimicrobial activity of the crude extracts of Houttuynia cordata and Centella asiatica on some human gut microflora
}

Research Article

\section{Madhusmita Bhagawati'; Hazarika N K ${ }^{1}$; Rajeev Sarmah2*}

1. PhD scholar, 2. Professor and Head, Department of Microbiology, Srimanta Sankardeva University of Health Science, Guwahati.

3. Associate Professor, Faculty of Science, Assam Down Town University. Guwahati.

\begin{abstract}
C. asiatica and $H$. cordata plants are used as vegetable since time immemorable by the people of Assam. These are also consumed for their medicinal values. Plenty of information on the action of the plants extract on the pathogens are available, but could not retrieve any information on the non-pathogens of human guts. Therefore, an attempt has been made to find action of the extracts on few of the non-pathogens of human guts. The study shows that none of the plant extracts inhibit Bacillus coagulans, Bacillus mesentricus, and Lactobacillus sp, whereas a minimum inhibition were recorded in case of pathogens Escherchia coli, Staphylococcus aureus, Klebsiella pneumoniae and Shigella dysenteriae.
\end{abstract}

Key Words: Plant Extracts, Inhibition zone, Pathogens and Non-pathogens.

\section{Introduction}

Centella asiatica, and Houttuynia cordata are plated as leafy vegetable by the people of North - East India. These plants are quite often used as herbal remedy against stomach infections by the people of Assam, India. Literature suggests that extracts of these plants have anti-microbial, anti-inflamatory, antioxidative properties and thus provides remedy not only to the gastrointestinal problems but also to other infections. Rattanachuaikunsopon and Phumkhachorn 2010) reported that the extract of $C$. asiatica among many plants is best against $F$. columnare (1). The study of Cheng and Koo, 2000 reported that C. asiatica extract accelerate cure of gastric lesions in rats (2). $\mathrm{NgLT}$ et al 2007, showed the protective effect of $H$. cordata extract on bleomycin induced pulmonary fibrosis in rats (3). Experiments also demonstrated the antidiarrheal activity of $H$. cordata (4). Although antimicrobial activity of $C$. asiatica was determined to be poor than antibiotics such as tetracycline, it showed bacteriostatic activity against isolates from wounds of different etiology. During the period of Severe Acute Respiratory Syndrome SARS) outbreak, H. cordata was one of the ingredients in the SARS prevention use for prevention. The formulation was recognised by health ministry of China (5). Recently several studies illustrated its anti-SARS (6), anti-allergic (7); ani-

\section{* Corresponding Author:}

Rajeev Sarmah

Associate Professor,

Faculty of Science,

Assam down town University, Guwahati

Assam. India.

Email Id: akendrarajeev@gmail.com inflamatory $(8,9)$; virucidal $(10,11)$; anti-Leukemic (12); anti-oxidative $(3,13)$ and anticancer activities (14).

The microbiome of human gut includes a wide range of both pathogenic and non-pathogenic microorganisms. Existing literatures mostly inferred on the antimicrobial activity of the extracts of $H$. cordata and $C$. asiatica against most of the pathogenic microorganisms. Literature survey on the actions of the extracts of these plants on non-pathogenic gut microorganisms could not provide much information. It is essentially important to know about the action of the plant extracts on the non-pathogenic microorganisms of the gut. It is also well established that the nonpathogens support human health. Therefore, in view to elucidate the antimicrobial activity of the said plants on the non-pathogens with respect to that on pathogens the present study was conceived. If the extract poise any adverse effect on non-pathogens, there lies the question of using pre or probiotic supplements along with the use of these plants as indigenous herbal composition or Ayurvedic composition.

\section{Materials and Methods}

\section{Bacterial Sample Isolation and Identification}

The pathogenic microorganisms Escherchia coli, Shigella dysenteriae, Klebsiella pneumoniae, Staphylococcus aureus were collected from various clinical specimen at Bacteriology laboratory, Microbiology, Department of Gauhati Medical College and Hospital. The non-Pathogenic bacteria Bacillus mesentricus and Bacillus coagulans are probiotic isolates and Lactobacillus sp. was collected from curd.

The pathogens were cultured in MacConkey and Blood agar media for identification. The identified colonies were then stored in Luria Bertani LB) broth 
Rajeev Sarmah et.al., Antimicrobial activity of Houttuynia cordata and Centella asiatica on some human gut microflora

and agar. For antimicrobial tests, the sub-cultures were prepared on Muller Hinton agar media and Nutrient Agar Media. LB broth was used for the purpose of analysis of minimum inhibitory concentration MIC).

A suspension of non-pathogens was prepared in peptone water and was streaked on the MRS De Man, Rogosa and Sharpe) agar media and further subcultured in Muller Hinton agar media.

Identification of the microorganisms was based on colonial characteristics and using various standard biochemical tests such as IMViC, Catalase test, Hi Assorted TM Biochemical test, $\mathrm{NaCl}$ tolerance test specifically for Non-pathogens.

\section{Preparation of Plant Extracts and Antimicrobial Property Analysis \\ Centella asiatica and Houttuynia cordata were} collected from the Agricultural Research Institute Kahhikushi, Guwahati, Assam India. Leaves of the plants were washed thoroughly before air drying and then powdered. The extracts were prepared in solvents such as chloroform, petroleum ether, benzene, acetone and methanol using soxhlet apparatus and stored in a sterile screw capped bottle at $-20^{\circ} \mathrm{C}$. In addition, leave extracts were also prepared by cold maceration method. In this method, the dried powder was kept dissolved in chloroform, benzene, acetone and methanol for 72 hours. Under reduced pressure the extracts were evaporated and dried by using a rotary evaporator.

Antimicrobial activity of the extracts thus obtained were analyzed by standard well-diffusion technique and Minimum Inhibitory Concentration using Resazurin Dye.

\section{Characterization of plant extract}

Thin Layer Chromatography TLC) was performed on TLC silica gel 60 F254, aluminium sheet $20 \times 20 \mathrm{~cm}$. After drying the plates, they were exposed to Iodine vapor for obtaining colored spots spot. The $\mathrm{R} f$ value of the different spots that were recorded. A preparative TLC was performed on glass silica film with the known potent solvent mixture to get the fraction.

\section{GC-MS Analysis for Plant samples:}

Shimadzu GC 2010 plus with triple MS TP-8030) fitted with EB-5MS column was used for the purpose. The temperature program for the column was set at $100^{\circ} \mathrm{C}$ hold for $1 \mathrm{~min}, 15^{\circ} \mathrm{C} / \mathrm{min}$ to $160^{\circ} \mathrm{C}$ and $5^{\circ} \mathrm{C} / \mathrm{min}$ to $300^{\circ} \mathrm{C}$ hold for $7 \mathrm{~min}$. The $\mathrm{GC}$ injector was held isothermally at $280^{\circ} \mathrm{C}$ with a split period of $3 \mathrm{~min}$, as the carrier gas Helium was used, at a flow rate of 1 $\mathrm{mL} / \mathrm{min}$ by using electronic pressure control. The interface temperature for GC-MS was maintained at $280^{\circ} \mathrm{C}$. In electron impact EI) ionization mode, the MS was operated with $70 \mathrm{eV}$ electron energy and the scan to determine appropriate masses for selected ion monitoring ranged from 50 to $500 \mathrm{amu}$ atomic mass unit).

\section{Results}

The pathogens and nonpathogens

Based on the colonial characteristics followed by standard biochemical tests the microorganisms were identified to be E.coli, $K$. pneumoniae, $S$. dysentriae, $S$. aureus Table - 1). Similarly, the non-pathogens were identified to be $B$. coagulans, $B$. messentricus and were isolated from probiotic Bifalac sachet and $L$. acidophillus was isolated from curd Table -2 ).

\begin{tabular}{|c|c|c|c|c|c|c|c|c|c|c|c|c|c|}
\hline \multirow{2}{*}{ SI } & Bacteria & & \multicolumn{11}{|c|}{ Table 1. Biochemical Test Results of Pathogenic Bacteria for identification } \\
\hline & & Characteristics & GS & MO & IN & MR & VP & CO & CI & CA & OD & NR & SR \\
\hline 1 & E. coli & $\begin{array}{l}\text { Moist smooth } \\
\text { surface pink in } \\
\text { MacConky/ } \\
\text { cled, bacillus } \\
\text { slender \& thin. }\end{array}$ & - & + & + & + & - & - & - & + & - & + & Glucose+ \\
\hline & & $\begin{array}{l}\text { Coccus } \\
\text { Clustered }\end{array}$ & & & & & & & & & & & $\begin{array}{l}\text { Glucose+ } \\
\text { Lactose+ }\end{array}$ \\
\hline 2 & aeurus & $\begin{array}{l}\text { colony, show b- } \\
\text { hemolysis in } \\
\text { blood agar plate }\end{array}$ & + & - & - & + & + & + & + & + & - & + & Mallose+ \\
\hline 3 & $\begin{array}{l}\text { Klebsela } \\
\text { pneumonia }\end{array}$ & $\begin{array}{l}\text { Mucoid bluish } \\
\text { pink in cled/ } \\
\text { MacConky } \\
\text { medium, basilus } \\
\text { and stout }\end{array}$ & - & + & - & - & - & & + & + & - & + & \\
\hline 4 & S dysentreae & $\begin{array}{l}\text { Hemolytic } \\
\text { colony, colony } \\
\text { circular } \\
\text { colourless, } \\
\text { convex but } \\
\text { moderately } \\
\text { translucent with } \\
\text { smooth surface } \\
\text { and entire } \\
\text { edges. }\end{array}$ & - & - & + & + & - & & - & + & & + & Glucose+ \\
\hline
\end{tabular}


GS - Gram Stain; MO - MobilityIN - Indole Test; MR - Methyl Red Test; VP - Voges- proskaver Tesr;

CO - Coagulate Test; CI - Citrate Reductase Test; CA - Catalase Test; OD - Oxydase Test;

NR - Nitrate reductase Test; SR - Sugar Test

Table 2. Biochemical Test Results of Non-Pathogenic Bacteria for identification

\begin{tabular}{|c|c|c|c|c|c|c|c|c|c|c|c|c|c|}
\hline SI & Bacteria & $\begin{array}{l}\text { Colony } \\
\text { Characteristics }\end{array}$ & GS & MO & IN & MR & $\mathbf{V P}$ & $\mathrm{CO}$ & CI & CA & OD & NR & SR \\
\hline 1 & $\begin{array}{l}\text { Bacillus } \\
\text { coagulans }\end{array}$ & $\begin{array}{l}\text { The organism } \\
\text { with convex, } \\
\text { entire margined } \\
\text { and smooth } \\
\text { surfaced } \\
\text { colonies, white } \\
\text { to cream in } \\
\text { colour and did } \\
\text { not grow in } 7 \% \\
\text { NaCl containing } \\
\text { media was } \\
\text { identified to be } \\
\text { Bacillus } \\
\text { coagulans }\end{array}$ & + & + & - & + & - & + & + & + & - & - & $\begin{array}{l}\text { Maltose- } \\
\text { Glucose+ }\end{array}$ \\
\hline 2 & $\begin{array}{l}\text { Bacillus } \\
\text { mecentricus }\end{array}$ & $\begin{array}{l}\text { Elipsoidal } \\
\text { spores. The } \\
\text { colonies are } \\
\text { irregular,wrinkl } \\
\text { ed and } \\
\text { pointed.They } \\
\text { are smooth, } \\
\text { opaque and } \\
\text { unpigmented,sli } \\
\text { ghtly } \\
\text { yellowish.non- } \\
\text { haemolytic } \\
\text { when cultured } \\
\text { in sheeep } \\
\text { blood-agar } \\
\text { media. }\end{array}$ & + & + & - & + & + & - & + & + & - & - & $\begin{array}{l}\text { Glucose+ } \\
\text { Fructose+ }\end{array}$ \\
\hline 3 & $\begin{array}{l}\text { Lactobacillus } \\
\text { sp. }\end{array}$ & $\begin{array}{l}\text { The } \\
\text { coloniessmall to } \\
\text { medium gray } \\
\text { colonies that } \\
\text { usually exhibit } \\
\text { alpha hemolysis } \\
\text { on blood agar } \\
\text { are, mucoid } \\
\text { colony, white in } \\
\text { MRS, }\end{array}$ & + & - & - & - & - & - & - & - & - & - & $\begin{array}{l}\text { Lactose }+ \\
\text { Glucose }+\end{array}$ \\
\hline
\end{tabular}

\section{Antimicrobial Activity Analysis}

The antimicrobial activity analysis of the extracts was performed by well diffusion and Minimum Inhibitory Concentration methods. The resulting zone of inhibition were measured in millimeter. The resampling values at $\mathrm{P}<0.05$ is illustrated in Table 3 . The results reveal that the extract have inhibitory effect with varied range depending on the microorganism and the solvent used for extraction. The experiment also has shown that crude extracts of both $H$. cordata and $C$. asiatica, irrespective of nature of isolation distinctly inhibit the growth of E. coli and $S$. dysenteriae. However, extent of inhibition by the extracts significantly varies. It has been observed that chloroform and methanol extracts of $C$. asiatica were more effective against $E$. coli $11.65 \pm$ 0.00 and $13.67 \pm 0.01$ respectively. Acetone, chloroform 
Rajeev Sarmah et.al., Antimicrobial activity of Houttuynia cordata and Centella asiatica on some human gut microflora

and methanol extracts of $C$. asiatica seems to be almost equally inhibiting $S$. dysenteriae. However, no inhibition was seen against $K$. pneumonia by the extract of $C$. asiatica. A varying and insignificant inhibition was observed in case of $S$. aureus by the extracts of $C$. asiatica. On the other hand, the extracts of $H$. cordata seems to inhibiting $K$. pneumonia and $S$. aureus. The extracts prepared in solvents chloroform, methanol acetone, benzene, and petroleum ether of $H$. cordata was found to be effective against $E$. coli, $S$. dysenteriae and $K$. pneumoniae. Acetone and chloroform extract of $H$. cordata even showed antimicrobial activity against $S$. aureus with small sized zone.

\begin{tabular}{|c|c|c|c|c|c|c|}
\hline Organism & Plant Species & Acetone & Chloroform & Methanol & Benzene & P. Ether \\
\hline \multirow{2}{*}{ E. coli } & C. asiatica & $5.01 \pm 0.00$ & $11.65 \pm 0.00$ & $13.67 \pm 0.01$ & - & - \\
\hline & H. cordata & - & $8.64 \pm 0.02$ & $6.34 \pm 0.01$ & $5.99 \pm 0.01$ & $12.33 \pm 0.01$ \\
\hline \multirow{2}{*}{ K. pneumonia } & C. asiatica & \multicolumn{5}{|c|}{ NO ACTIVITY SEEN } \\
\hline & H. cordata & $7.69 \pm 0.01$ & $15.64 \pm 0.01$ & $9.66 \pm 0.01$ & $8.99 \pm 0.02$ & $11.99 \pm 0.01$ \\
\hline \multirow{2}{*}{ S.aureus } & C. asiatica & $4.67 \pm 0.00$ & $9 \pm 0.01$ & $7.65 \pm 0.01$ & - & - \\
\hline & H. cordata & $4.99 \pm 0.00$ & $3.67 \pm 0.01$ & - & - & - \\
\hline \multirow{2}{*}{ S. dysenteriae } & C. asiatica & $10.32 \pm 0.00$ & $11 \pm 0.00$ & $12 \pm 0.00$ & - & - \\
\hline & H. cordata & $12.67 \pm 0.01$ & $14.66 \pm 0.01$ & $17.66 \pm 0.01$ & $12.67 \pm 0.01$ & $8.66 \pm 0.02$ \\
\hline
\end{tabular}

The Minimum inhibitory concentration was determined by calculating the lowest concentration of the plant extract that inhibited visible growth of the test microorganism. The lowest concentration of the plant extract at which the color change occurred was taken as the MIC value. From the triplicate the arithmetic average were considered. The MIC values of $H$. cordata and $C$. asiatica tested against the pathogenic bacteria are presented in Table 4 . The MIC value of different extracts fall in the range within $0.36 \mathrm{mg} / \mathrm{ml}$ to $2.5 \mathrm{mg} /$ $\mathrm{ml}$ as determined by resazurin based microtitre plate assay. Although the inhibitory zone formed by the extracts of $C$. asiatica in case of $S$. aureus was varying, evident from significantly non-uniform results but it has been observed that a very low concentration is required for inhibition i.e $\sim 0.83 \mathrm{mg}$ which is contradicting. Better and uniform results however, was observed in case of $S$. dysentriae and E. coli. All the extracts of $H$. cordata seems to be insignificantly varying when a particular type of organism is considered at $\mathrm{P}<0.05$. However, the required concentration for inhibition significantly varies from organism to organism P-value $0.95)$.

Table 4. Minimum Inhibitory Concentration of various extracts of $\boldsymbol{C}$. asiatica and $\boldsymbol{H}$. cordata on bacteria

\begin{tabular}{|c|c|c|c|c|c|c|c|}
\hline \multirow{2}{*}{ Plant } & \multirow{2}{*}{ Extracts } & \multirow{2}{*}{ Bacteria } & \multicolumn{5}{|c|}{ Minimum Inhibitory Concentration in mg) } \\
\hline & & & $\mathbf{1}$ & 2 & 3 & Mean & P-Value \\
\hline \multirow{9}{*}{ C. asiatica } & \multirow{3}{*}{ Acetone } & S. dysentriae & 2.5 & 2.5 & 2.5 & 2.5 & 0.06 \\
\hline & & E. coli & 0.62 & 1.25 & 1.25 & 1.05 & 0.20 \\
\hline & & S. aureus & 1.25 & 2.5 & 1.25 & 1.6 & 0.13 \\
\hline & \multirow{3}{*}{ Methanol } & S. dysentriae & 1.25 & 1.25 & 1.25 & 1.25 & 0.17 \\
\hline & & E. coli & 2.5 & 2.5 & 2.5 & 2.5 & 0.06 \\
\hline & & S. aureus & 1.25 & 0.62 & 0.62 & 0.83 & 0.25 \\
\hline & \multirow{3}{*}{ Chloroform } & S. dysentriae & 1.25 & 2.5 & 2.5 & 2.08 & 0.09 \\
\hline & & E. coli & 2.5 & 2.5 & 2.5 & 2.5 & 0.06 \\
\hline & & S. aureus & 0.62 & 1.25 & 1.25 & 1.04 & 0.20 \\
\hline \multirow{12}{*}{ H. cordata } & \multirow{4}{*}{ Acetone } & S. dysentriae & 1.25 & 1.25 & 1.25 & 1.25 & 0.17 \\
\hline & & E. coli & 2.5 & 2.5 & 2.5 & 2.5 & 0.06 \\
\hline & & S. aureus & 2.5 & 2.5 & 2.5 & 2.5 & 0.06 \\
\hline & & K. pneumonia & 2.5 & 2.5 & 2.5 & 2.5 & 0.06 \\
\hline & \multirow{4}{*}{ Methanol } & S. dysenteriae & 0.15 & 0.15 & 0.31 & 0.4 & 0.36 \\
\hline & & E. coli & 2.5 & 2.5 & 2.5 & 2.5 & 0.06 \\
\hline & & S. aureus & 1.25 & 1.25 & 2.5 & 1.6 & 0.13 \\
\hline & & K. pneumoniae & 2.5 & 2.5 & 2.5 & 2.5 & 0.06 \\
\hline & \multirow{4}{*}{ Chloroform } & S. dysentriae & 0.62 & 0.31 & 0.15 & 0.36 & 0.38 \\
\hline & & E. coli & 2.5 & 2.5 & 2.5 & 2.5 & 0.06 \\
\hline & & S. aureus & 2.5 & 2.5 & 2.5 & 2.5 & 0.06 \\
\hline & & K. pneumoniae & 2.5 & 2.5 & 2.5 & 2.5 & 0.06 \\
\hline
\end{tabular}

\section{Fractionation of plant extract}

Preparative TLC with a thickness of $1 \mathrm{~mm}$ silica gel as well as TLC silica gel 60 F245 aluminum sheet $20 \times 20 \mathrm{~cm}$, was used to separate different components of the crude extracts of the two plants Table 5). The different solvents used for the fractionation were methanol, chloroform, acetic acid and ethanol at varied ratio.

The most prominent fraction spotted on TLC were scrapped and then dissolved in DCM Dichloromethane), filtered and centrifuged and finally given for GC-MS, analysis. The gas chromatography characterized the compounds present in the fractions of 
$H$. cordata and $C$. asiatica by comparison of mass spectra on NIST library. Those peaks matching similarity index greater than $70 \%$ in the NIST library were assigned. The library search of the highest peaks revealed five basic compounds Benzenamine, Cyclotetrasiloxane, N-2-Ethylhexyl) trifluoroacetamide11- Methyldodecanol in case of $H$. cordata extracts Figure 1). GCMS chromatogram analysis of $C$. asiatica showed four predominant peaks with high percentage namely bicyclo(7.2.0)undec-4ene,4,11,11-trimethyl-8-methylene ,(1r.1r*,4z,93*)) ; aryophylene;1,2-benzenedicarboxylic acid, bis2methylpropyl) ester 1 h-3a,7-methanoazulene, octahydro-1,4,9,9-tetramethyl Figure 2).

\begin{tabular}{|c|c|c|c|c|}
\hline \multicolumn{5}{|c|}{ Table 5 TLC fractions of the extracts } \\
\hline Plant & Extracts & Solvent System & $\begin{array}{l}\text { No. of } \\
\text { Fractions }\end{array}$ & Rf. Values \\
\hline \multirow{6}{*}{ H. cordata } & Acetone & \multirow{4}{*}{ Chloroform : Ethanol 3:7) } & 2 & $0.80 ; 0.68$ \\
\hline & Methanol & & 2 & $0.73 ; 0.65$ \\
\hline & Chloroform & & 2 & $0.75 ; 0.61$ \\
\hline & P. Ether & & 2 & $0.73 ; 0.61$ \\
\hline & Benzene & \multirow{2}{*}{ Choloroform : Benzene 7:3) } & 5 & $0.86 ; 0.30 ; 0.23 ; 0.16 ; 0.11$ \\
\hline & P. Ether & & 5 & $0.90 ; 0.60 ; 0.20 ; 0.11 ; 0.09$ \\
\hline \multirow{6}{*}{ C. asiatica } & Acetone & \multirow{3}{*}{ Chloroform : Methanol 9:1) } & 3 & $0.88 ; 0.82 ; 0.78$ \\
\hline & Chloroform & & 3 & $0.86 ; 0.78 ; 0.74$ \\
\hline & Methanol & & 3 & $0.84 ; 0.78 ; 0.72$ \\
\hline & Acetone & \multirow{3}{*}{$\begin{array}{l}\text { Chloroform : Glacial acetate : } \\
\text { Methanol : Water } 6: 2: 1: 1)\end{array}$} & 3 & $0.95 ; 0.71 ; 0.47$ \\
\hline & Chloroform & & 4 & $0.86 ; 0.63 ; 0.52 ; 0.36$ \\
\hline & Methanol & & 3 & $0.89 ; 0.67 ; 0.47$ \\
\hline
\end{tabular}

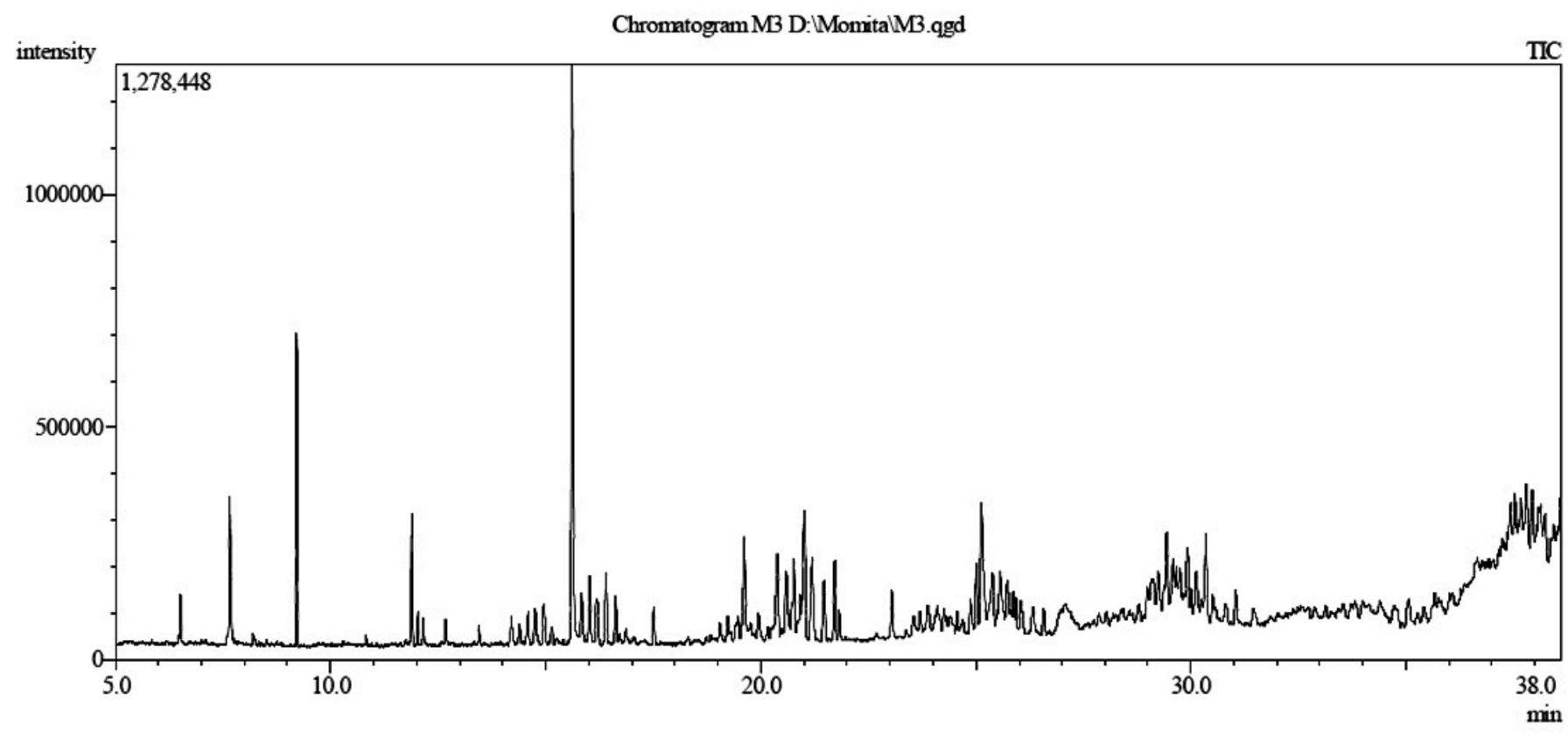

Figure 1: GC/MS analysis Clarus 680 GC/Clarus $600 \mathrm{C}$ MS was used using Capillary column: Elite-5MS. For H. cordata. 


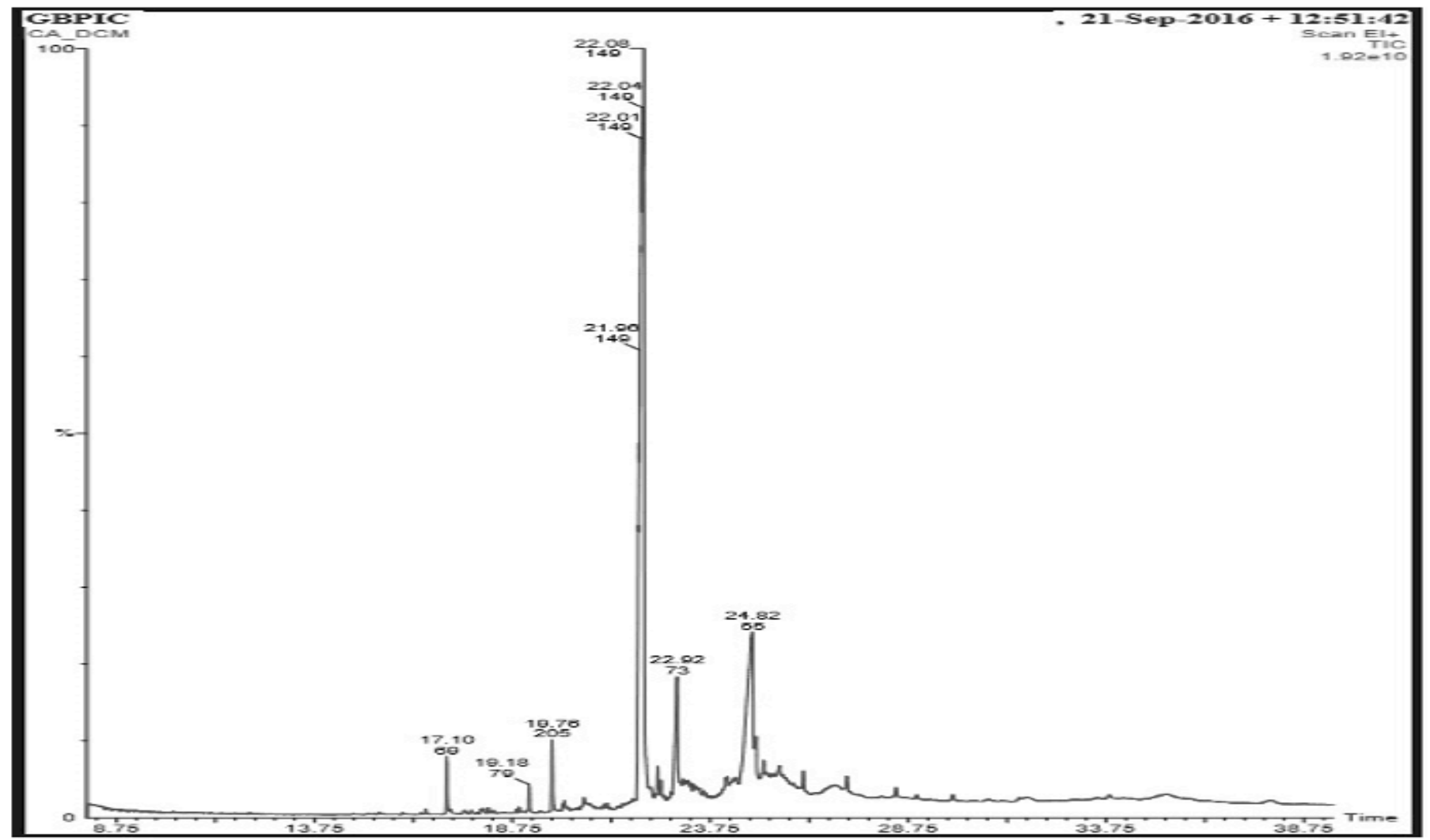

Figure 2: GC/MS analysis Clarus 680 GC/Clarus 600 C MS was used using Capillary column:Elite-5MS. For C. asiatica.

Comparative analysis on the use of antibiotics and the plant extracts to the pathogen as well as nonpathogens.

The comparative analysis was performed based on the formation and size the zone of inhibitions. For the purpose comparation susceptible antibiotic disks were used along with pants extracts in wells on bacterial culture inoculated in MHA media. A comparative analysis was performed using known antibiotic
Gentamycin GEN) and the best extract performer Table 6). It has been observed that although the size of inhibition zone is smaller comparative to that of the zone of inhibition former by the antibiotics they inhibit the growth of the pathogenic microorganisms. It is interesting to observe that none of the non-pathogens were affected by the extracts. If the concentration of the extracts increases it may be possible to inhibit the growth of all of the pathogen.

\begin{tabular}{|c|c|c|c|c|}
\hline \multicolumn{5}{|c|}{ Table 6: Inhibitory activity of known antibiotics and plant extracts a comparison } \\
\hline Organisms & Antibiotic & Zone size mm) & Plant extracts & Zone size \\
\hline \multirow{2}{*}{ Shigella dysentraie } & \multirow{2}{*}{ GEN } & \multirow[t]{2}{*}{ ( } & CA methanol) & $12 \pm 0.00$ \\
\hline & & & HC methanol) & $17.66 \pm 0.01$ \\
\hline \multirow{2}{*}{$\begin{array}{l}\text { Staphylococcus } \\
\text { aureus }\end{array}$} & \multirow{2}{*}{ GEN } & \multirow{2}{*}{15} & CA Chloroform) & $9 \pm 0.01$ \\
\hline & & & HC Methanol) & $4.99 \pm 0.00$ \\
\hline \multirow{2}{*}{ E. coli } & \multirow{2}{*}{ GEN } & \multirow{2}{*}{18} & CA Methanol) & $13.67 \pm 0.01$ \\
\hline & & & HC P. Ether) & $12.33 \pm 0.01$ \\
\hline B. coagulans & GEN & 15 & PLANT EXTRACTS & NIL \\
\hline B. mecentricus & GEN & 22 & & \\
\hline Lactobacillus sp & GEN & 24 & & \\
\hline
\end{tabular}

\section{Discussion}

The increase of multidrug resistant microorganism poises a major threat to human population worldwide. Therefore, search for newer drug molecule is becoming a continuous process. The present study is an effort to detect, antimicrobial property that exists if any in $C$. asiatica and $H$. cordata. If it has such property what is the extent it can inhibit harmful and useful bacteria of human gut. The experimental findings suggest that the extracts of both the plants inhibit the pathogens but interestingly do not inhibit the nonpathogens.

In the present study, the screening of plant extracts showed good range phytochemical having antimicrobial activity specially, against $E$. coli and $S$. dysenteriae. When compared the inhibitory zone size chloroform and methanol extracts of both $H$. cordata and $C$. asiatica showed most effective antimicrobial 
activity then benzene and petroleum ether extracts. However, extracts of both the plants also have shown significant inhibitory zone against $K$. pneumonia and $S$. dysenteriae. The antimicrobial activity was considered when the zone of inhibition is greater than $5 \mathrm{~mm}$ (15), this study has found that S. auerus although are inhibited but the zone size were less than $5 \mathrm{~mm}$. They also state that $A$. sativum extracts showed better activity against $E$. coli in disc diffusion method rather than well diffusion method. Therefore, it is possible to encounter a different result depending on the methods adopted. $H$. cordata extracts is found to be more effective than $C$. asiatica. $H$. cordata showed most effective result against $S$. dysenteriae and least against $S$. aureus. Jacob et. al. (16) did not find any antimicrobial activity of water and ethanol extracts of $C$. asiatica against $E$. coli and $S$. aureus. This may be because of the concentrations of the extracts. The study of $\mathrm{M}$. Senthikumar (17) showed that higher concentration of ethanol, benzene and chloroform extracts of $C$. asiatica has antimicrobial activity against $K$. pneumonia on the contrary in this study no action has been recorded against $K$. pneumonia. The difference in antimicrobial activity of $H$. cordata and $C$. asiatica in the present study as well as the previous studies may be attributed to the age of the plants, geographical location, climatic conditions, and extraction procedures.

The potency of the plant extracts was quantified by evaluating the minimum concentration at which they inhibited the growth of the pathogens. The present study have shown the range of MIC values ranged from minimum $0.36 \mathrm{mg} / \mathrm{ml}$ to maximum $2.5 \mathrm{mg} / \mathrm{ml}$ for different extracts of both $H$. cordata and $C$. asiatica. Amongst all extracts methanol extract of $H$. cordata showed highest potency with least MIC value $0.36 \mathrm{mg} /$ $\mathrm{ml}$ and $0.40 \mathrm{mg} / \mathrm{ml}$ respectively that inhibited the growth of $S$. dysenteriae. On the other hand extracts of $C$. asiatica showed varied range against $S$. dysenteriae minimum range was shown by methanol extract $2.5 \mathrm{mg} /$ $\mathrm{ml}$. Acetone extract and chloroform extract of $C$. asiatica showed almost similar value i.e. $2.5 \mathrm{mg} / \mathrm{ml}$ and $2.08 \mathrm{mg} / \mathrm{ml}$ respectively. It was also observed that all the extract of $H$. cordata and $C$. asiatica showed similar range of MIC value i.e. $2.5 \mathrm{mg} / \mathrm{ml}$ except acetone extract $C$. asiatica with MIC value $1.05 \mathrm{mg} / \mathrm{ml}$.

The MIC tested against $S$. aureus by all the extract of $H$. cordata and $C$. asiatica showed a mix range of values. The MIC value of acetone and chloroform extract of $H$. cordata was similar that is 2.5 $\mathrm{mg} / \mathrm{ml}$ against $S$. aureus and $K$. pneumonia. But that of methanol extract was $1.6 \mathrm{mg} / \mathrm{ml}$ against $S$. aureus. A previous report (16) also showed MIC value of ethyl acetate extract of $H$. cordata to be $2.5 \mathrm{mg} / \mathrm{ml}$. However, no significant results was found against $E$. coli and $S$. aureus by $H$. cordata extracts. In another report (18) the MIC value against $S$. aureus of water extract of fresh and dry $H$. cordata were 12.5 and $100 \mathrm{mg} / \mathrm{ml}$ and those of ethanol extract 25 and $100 \mathrm{mg} / \mathrm{ml}$ respectively, which were extremely high as compared to the present study (19). The MIC value of methanol, acetone and chloroform extracts of $C$. asiatica ranged in order of $2.05 \mathrm{mg} / \mathrm{ml}, 1.6 \mathrm{mg} / \mathrm{ml}$ and $1.04 \mathrm{mg} / \mathrm{ml}$ against $S$. aureus. The results were very low compared to previous work where MIC values of ethanol extracts of leaf powder of $C$. asiatica showed $8 \mathrm{mg} / \mathrm{ml}$ and water extracts of leaf powder of C. asiatica showed $32 \mathrm{mg} / \mathrm{ml}$ against $S$. aureus (20). The present work results are in agreement with Phadet et. al. 2002) (21) which reports MIC values less than $5 \mathrm{mg} / \mathrm{ml}$ for ethanol extract 2.5 $\mathrm{mg} / \mathrm{ml}$ for water extract. The difference in the MIC values can be because of the variations in method of extractions water and solvents) and strains of pathogens or may be because of the area of collection of the plant specimens.

\section{Conclusion}

C. asiatica and $H$. cordata are important herb used as vegetable as well as ethno-medicine for gasteroenteric diseases since time immemorial. The present study reveals that the extracts of both the plant likely to be effective against $S$. dysenteriae and E. coli pathogen) without inhibiting non-pathogenic bacteria. The plant extracts have potential compounds that confirms as targeting pathogen rather than host beneficial bacteria. Therefore, $C$. asiatica and $H$. cordata, may be used as an alternative to antibiotics together with antibiotics against $S$. dysenteriae and other pathogens.

\section{Acknowledgement}

The Authors are heartly thankful to the Srimanta Sankardeva University of Health Science and Assam down town University for facilitating for the successful completion of the research.

\section{References}

1. Rattanachaikunsopon P, Phumkhachorn P. Use of Asiatic pennywort Centella asiatica aqueous extract as a bath treatment to control columnaris in Nile tilapia. Journal of aquatic animal health. 2010 Mar 1;22(1):14-20.

2. Cheng CL, Koo MW. Effects of Centella asiatica on ethanol induced gastric mucosal lesions in rats. Life sciences. 2000 Oct 13;67(21):2647-53.

3. Ng LT, Yen FL, Liao CW, Lin CC. Protective effect of Houttuynia cordata extract on bleomycininduced pulmonary fibrosis in rats. The American journal of Chinese medicine. 2007;35(03):465-75.

4. Bhagawati M, Hazarika NK, Baishya MK, Saikia K, Pegu DK, Sarmah R. Effect of Centella asiatica extracts on shigella dysenteriae and bacillus coagulans compared to commonly used antibiotics. Journal of Pharmaceutical, Chemical and Biological Sciences. 2018;5:337-44.

5. Lau KM, Lee KM, Koon CM, Cheung CS, Lau CP, Ho HM, Lee MY, Au SW, Cheng CH, Bik-San Lau $\mathrm{C}$, Tsui SK. Immunomodulatory and anti-SARS activities of Houttuynia cordata. Journal of Ethnopharmacology. 2008 Jun 19;118(1):79-85.

6. Kim IS, Kim JH, Kim JS, Yun CY, Kim DH, Lee JS. The inhibitory effect of Houttuynia cordata extract on stem cell factor-induced HMC-1 cell 
Rajeev Sarmah et.al., Antimicrobial activity of Houttuynia cordata and Centella asiatica on some human gut microflora

migration. Journal of Ethnopharmacology. 2007 May 30;112(1):90-5.

7. Li GZ, Chai OH, Lee MS, Han EH, Kim HT, Song $\mathrm{CH}$. Inhibitory effects of Houttuynia cordata water extracts on anaphylactic reaction and mast cell activation. Biological and Pharmaceutical Bulletin. 2005;28(10):1864-8.

8. Lu HM, Liang YZ, Yi LZ, Wu XJ. Antiinflammatory effect of Houttuynia cordata injection. Journal of Ethnopharmacology. 2006 Mar 8;104(1-2):245-9.

9. Park E, Kum S, Wang C, Park SY, Kim BS, Schuller-Levis G. Anti-inflammatory activity of herbal medicines: inhibition of nitric oxide production and tumor necrosis factor- $\alpha$ secretion in an activated macrophage-like cell line. The American Journal of Chinese Medicine. 2005;33(03):415-24.

10. Hayashi K, Kamiya M, Hayashi T. Virucidal effects of the steam distillate from Houttuynia cordata and its components on HSV-1, influenza virus, and HIV. Planta medica. 1995 Jun;61(03):237-41.

11. Chiang LC, Chang JS, Chen CC, Ng LT, Lin CC. Anti-Herpes simplex virus activity of Bidens pilosa and Houttuynia cordata. The American journal of Chinese medicine. 2003;31(03):355-62.

12. Chang JS, Chiang LC, Chen CC, Liu LT, Wang KC, Lin CC. Antileukemic activity of Bidens pilosa L. var. minor (Blume) Sherff and Houttuynia cordata Thunb. The American journal of Chinese medicine. 2001;29(02):303-12.

13. Chen YY, LIU TF, Chen CM, Chao PY, Chang TJ. A study of the antioxidative and antimutagenic effects of Houttuynia cordata Thunb. using an oxidized frying oil-fed model. Journal of nutritional science and vitaminology. 2003;49(5):327-33.

14. Kim SK, Ryu SY, No J, Choi SU, Kim YS. Cytotoxic alkaloids fromHouttuynia cordate. Archives of pharmacal research. 2001 Dec 1;24(6):518-21.

15. Jouda MM, Elbashiti T, Masad A, Albayoumi M. The antibacterial effect of some medicinal plant extracts and their synergistic effect with antibiotics. World J Pharm Sci. 2015 Dec 4;5(2):23-33.

16. Jacob SJ, Shenbagaraman S. Evaluation of antioxidant and antimicrobial activities of the selected green leafy vegetables. Int. J. Pharm. Tech. Res. 2011 Jan;3(1):148-52.

17. Senthilkumar M. Investigations on quantification of bioactive compounds and in vitro antibacterial property of important medicinal plant of Centella asiatica (L.) urban. system.;12:13.

18. MENG J, ZONG XP, DONG XP. Study on Pharmacological Effects of Fresh and Dry Houttuynia cordata Thunb.[J]. Lishizhen Medicine and Materia Medica Research. 2008;6.

19. Jiangang $F$, Ling $D$, Zhang L, Hongmei L. Houttuynia cordata Thunb: a review of phytochemistry and pharmacology and quality control. Chinese Medicine. 2013 Aug 21;2013.

20. Taemchuay D, Rukkwamsuk T, Sakpuaram T, Ruangwises N. Antibacterial activity of crude extracts of Centella asiatica against Staphylococcus aureus in bovine mastitis. Kasetsart Veterinarians. 2009;19(3):119-28.

21. Seevaratnam V, Banumathi $P$, Premalatha MR, Sundaram SP, Arumugam T. Functional properties of Centella asiatica (L.): a review. Int J Pharm Pharm Sci. 2012;4(5):8-14. 